\title{
Family-friendly Policies for Rural Working Mothers
}

\author{
REB EC C A GLAUB E R
}

$\mathrm{T}$ he past four decades have ushered in dramatic changes in women's labor force participation. In 1968, just over 20 percent of mothers with infants worked for pay. Today more than half of all mothers with infants work for pay, making two-parent working families the norm rather than the exception. ${ }^{1}$ Despite these changes, institutional supports for working families lag behind. Many parents feel torn between obligations to their families and to their employers. Many parents wish for longer days and more time to spend with their children. And many children spend a significant amount of time worrying about their working parents. ${ }^{2}$

The rise in economic instability, inequality, and the "24/7" nature of the economy foretell an increase in parents' workfamily conflict over the coming years. Moreover, as the population ages, more parents are caught among three primary roles-worker, child caretaker, and elderly caretaker. ${ }^{3}$

Some employers have responded to these large-scale changes by providing their workers with flexible work arrangements, on-site childcare, paid parental leave, paid sick days, health insurance, dental insurance, job training, and other so-called "family-friendly" benefits or policies. ${ }^{4}$ These policies are costly to employers in the short term, but by increasing worker productivity and by reducing absenteeism and job turnover, they add value in the long term. ${ }^{5}$ Of course, these policies may also reduce parents' workfamily conflict. Family-friendly policies protect workers and their families from job loss, wage loss, and health and economic crises. In turn, they may reduce marital discord and emotional stress, and they may enhance children's emotional, physical, and cognitive well-being. These policies are perhaps most important to low-income families who may not have the means to purchase market-based solutions to work-family conflict. For example, two-thirds of lowincome parents have either left a sick child home alone or lost a day's worth of pay to care for a sick child. ${ }^{6}$

In other advanced industrialized nations, paid sick time, health insurance, and paid parental leave are not considered "benefits" so much as they are considered a right of citizenship. This is not the case in the United States, where most workers rely on the goodwill of their employers to procure these benefits. As a consequence, some American workers have access to them, and other workers do not.

\begin{tabular}{|c|c|c|}
\hline & $\begin{array}{c}\text { Rural } \\
\text { Mothers } \\
(\mathrm{N}=2,155)\end{array}$ & $\begin{array}{c}\text { Urban } \\
\text { Mothers } \\
(\mathrm{N}=5,984)\end{array}$ \\
\hline Median hourly earnings & $\$ 16$ & $\$ 19$ \\
\hline Median annual earnings & $\$ 30,472$ & $\$ 35,936$ \\
\hline Median family income & $\$ 63,103$ & $\$ 74,000$ \\
\hline Average hours of work per week & 38 & 38 \\
\hline Percent with less than high school degree & $5 \%$ & $5 \%$ \\
\hline Percent with high school degree & $47 \%$ & $40 \%$ \\
\hline Percent with some college & $25 \%$ & $29 \%$ \\
\hline Percent with college degree & $23 \%$ & $27 \%$ \\
\hline $\begin{array}{l}\text { Percent working at establishment with } \\
0 \text { to } 24 \text { employees }\end{array}$ & $35 \%$ & $32 \%$ \\
\hline $\begin{array}{l}\text { Percent working at establishment with } \\
25 \text { to } 99 \text { employees }\end{array}$ & $25 \%$ & $26 \%$ \\
\hline $\begin{array}{l}\text { Percent working at establishment with } \\
100 \text { to } 499 \text { employees }\end{array}$ & $25 \%$ & $24 \%$ \\
\hline $\begin{array}{l}\text { Percent working at establishment with } \\
500 \text { or more employees }\end{array}$ & $16 \%$ & $18 \%$ \\
\hline $\begin{array}{l}\text { Percent working for firm with } \\
\text { multiple locations }\end{array}$ & $64 \%$ & $69 \%$ \\
\hline Percent unionized & $13 \%$ & $16 \%$ \\
\hline Average labor market experience (in weeks) & 887 & 889 \\
\hline Average tenure with current employer (in weeks) & 382 & 362 \\
\hline Percent in public sector & $31 \%$ & $30 \%$ \\
\hline Percent self-employed & $4 \%$ & $2 \%$ \\
\hline Percent married & $76 \%$ & $65 \%$ \\
\hline Average family size & 3.80 & 3.72 \\
\hline Average number of children in household & 1.92 & 1.90 \\
\hline Average age of youngest child in household & 12.03 & 11.78 \\
\hline
\end{tabular}

Note: See end of brief for a description of the sample and data.

Source: National Longitudinal Survey of Youth 2000-2006. 
This brief presents an analysis of differences in access to family-friendly policies between rural and urban mothers. Rural Americans are disadvantaged in income, education, and employment (see Table 1). As this brief shows, they are also less likely to have access to family-friendly policies. Compared to urban mothers, rural mothers are less likely to have access to paid sick days, health insurance, dental insurance, parental leave, flextime, and job training. Single mothers in rural America fare the worst, primarily because they have less education, they work for smaller firms, and they work in occupations and industries that are less likely to offer family-friendly benefits.

\section{Single Rural Mothers Have Less Access to Family-Friendly Policies}

In this brief I describe labor market outcomes for a select group of workers-those who are between the ages of 35 and 50 and work more than 20 hours per week. I refer to this group as relatively advantaged because these workers are reaching the peak of their labor market earnings and they have stable, full-time (or near full-time) employment. The differences between rural and urban workers that I discuss can be generalized only to this older group of workers, and the research findings most likely underestimate the differences between rural and urban Americans in general. For example, almost half of all private sector workers in the United States do not have any paid sick days. Among the relatively advantaged group described in this brief, 38 percent of rural workers and 30 percent of urban workers lack access to paid sick days. Sixteen percent of rural workers have no paid sick days and no paid vacation days.

As Table 2 indicates, rural workers are disadvantaged relative to their urban peers across all family-friendly policies. Almost one-fifth of rural workers do not have access to health insurance. Almost one-third do not have access to dental insurance, and nearly one-half do not have access to flextime and job training.

Single mothers may need health insurance and other family-friendly benefits more than married mothers, but they have less access to these benefits. Rural single mothers fare the worst. Forty-one percent of rural single mothers do not have access to paid sick days, and over one-fifth of rural single mothers do not have access to any paid days off (sick days or vacation days). As a result, they may face difficult choices between losing a day of pay and leaving a sick child at home alone.

\section{Education Increases Access to Family-Friendly Policies}

Education is a strong predictor of access to family-friendly policies. Over 80 percent of rural mothers without a high school degree work in jobs that do not provide access to training (see Figure 1). Over half work in jobs that do not provide dental insurance, parental leave, and paid sick days. Mothers at the bottom of the educational distributionboth rural and urban-not only work for low wages but also have less access to important family-friendly benefits. This lack of access makes it harder for lower-income workers to keep their jobs and it likely perpetuates educational and economic inequalities across generations.

\section{Why Do Rural Mothers Have Less Access to Family-Friendly Policies?}

There are a number of factors that contribute to the ruralurban gap in mothers' access to family-friendly policies. About half of the gap in access to sick or vacation days is due to differences between rural workers' and urban workers' work establishment size, occupation and industry, and unionization. ${ }^{7}$ Rural workers tend to work in smaller establishments and in occupations and industries that provide fewer family-friendly policies. Figure 2 shows that once we look at women who share the same occupation, some of the rural-urban gap in access subsides. Rural and urban professionals, managers, and technical and clerical support workers have similar levels of access to paid sick or vacation days. The gap in access, however, persists for sales workers. Rural sales workers are much less likely to have access to family-friendly policies than urban sales workers.

Differences in rural and urban industries account for a smaller portion of the rural-urban gap in access to familyfriendly policies. Older rural and urban mothers who work over 20 hours per week tend to be employed in similar industries. For example, about 38 percent of both urban and rural mothers work in professional service industries. Twelve percent of rural and 11 percent of urban mothers work in retail trade industries, and 13 percent of both groups work in nonprofessional service industries. Over 60 percent of rural and urban mothers work in just three industries-professional services, nonprofessional personal services, and retail trade. Although there are some differences between rural and urban mothers (for example, 12 percent of rural mothers and 9 percent of urban mothers 
TAble 2. Percentage of RURAl AND URBAN WORKers Aged 35 TO 50 Who WORK MORE THAN 20 HOURS PER WEEK AND DO NOT HAVE ACCESS TO FAMILY-FRIENDLY POLICIES

\begin{tabular}{|c|c|c|c|c|c|c|}
\hline \multirow[b]{2}{*}{ Do Not Have Access To } & \multicolumn{2}{|c|}{ All Workers } & \multicolumn{2}{|c|}{ Single Mothers } & \multicolumn{2}{|c|}{ Married Mothers } \\
\hline & Rural (\%) & Urban (\%) & Rural (\%) & Urban (\%) & Rural (\%) & Urban (\%) \\
\hline Paid sick days & 38 & 30 & 41 & 33 & 35 & 27 \\
\hline Either paid sick or paid vacation days & 16 & 14 & 21 & 17 & 13 & 11 \\
\hline Health insurance & 19 & 16 & 23 & 19 & 16 & 13 \\
\hline Dental insurance & 31 & 26 & 33 & 26 & 28 & 23 \\
\hline Parental leave & 31 & 27 & 33 & 27 & 29 & 24 \\
\hline Flextime & 48 & 42 & 49 & 42 & 45 & 41 \\
\hline Training & 46 & 41 & 51 & 44 & 41 & 36 \\
\hline
\end{tabular}

Note: See end of brief for a description of the sample and data.

Source: National Longitudinal Survey of Youth 2000-2006.

Figure 1. Percentage of MOthers Aged 35 TO 50 WHO DO NOT HAVE ACCESS TO FAMily-FriendLy POLICIES BY EDUCATION AND RURAL/URBAN RESIDENCE

\section{Urban Mothers}
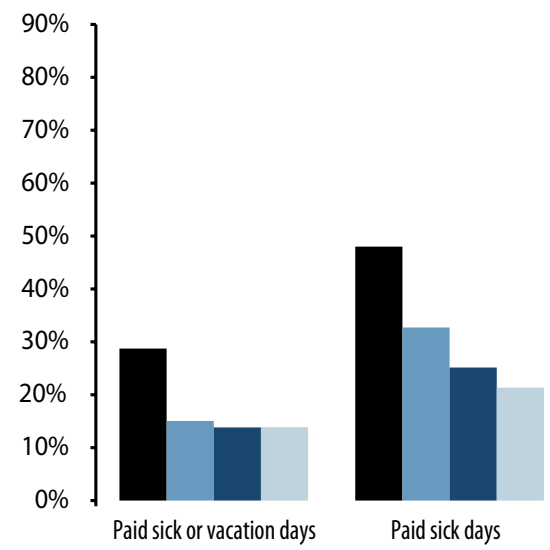

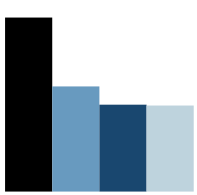

Health insurance

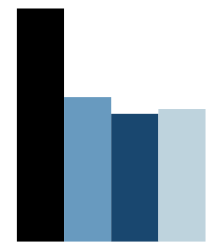

Dental insurance

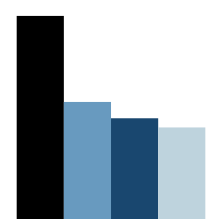

Parental leave

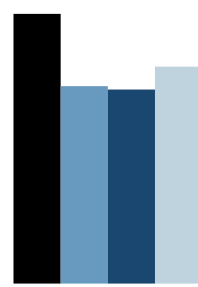

Flextime

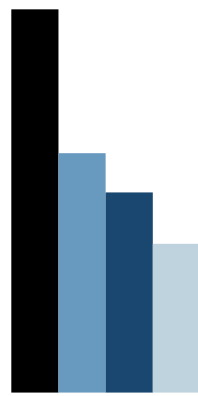

Training

\section{Rural Mothers}

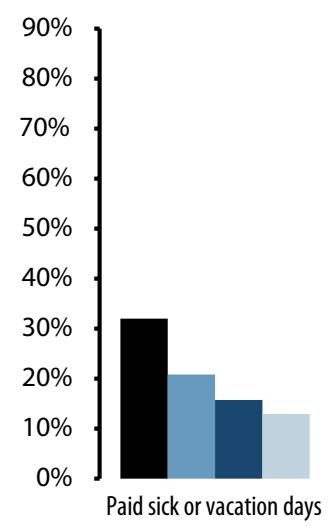

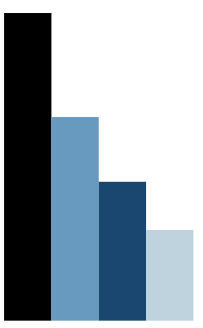

Paid sick days

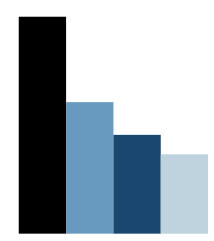

Health insurance

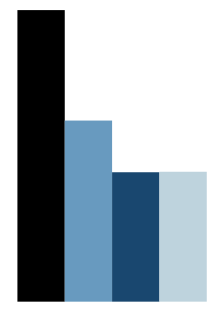

Dental insurance

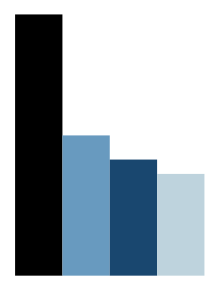

Parental leave

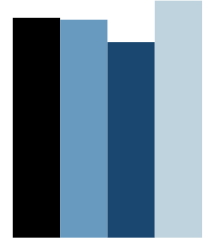

Flextime

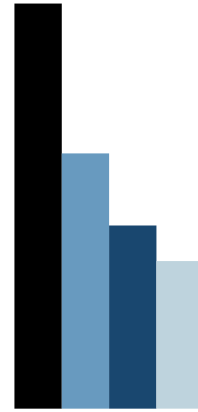

Training 


\section{CARSEY INSTITUTE}

Figure 2. Percentage of MOthers Aged 35 TO 50 WHO do NOT HAVE ACCESS TO ANy SiCK OR VACATION DAYS BY OCCUPATION AND RURAL/URBAN RESIDENCE

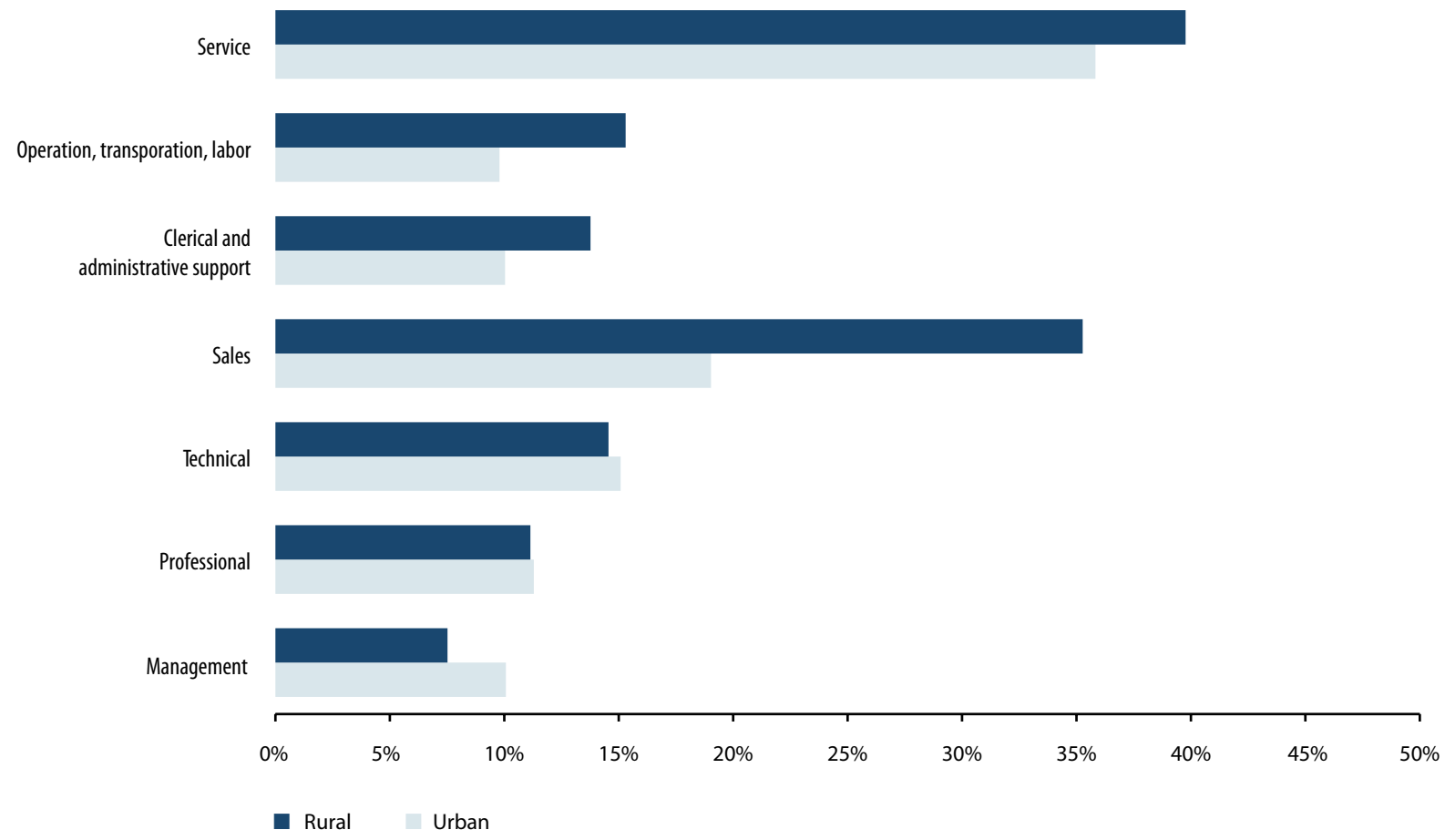

Source: National Longitudinal Survey of Youth 2000-2006.

Figure 3. Percentage of mothers Aged 35 to 50 Who do not haVe ACCess to ANy SiCK OR VACATION DAYS BY INDUSTRY AND RURAL/URBAN RESIDENCE

Manufacturing

Transporation and communication

Retail trade

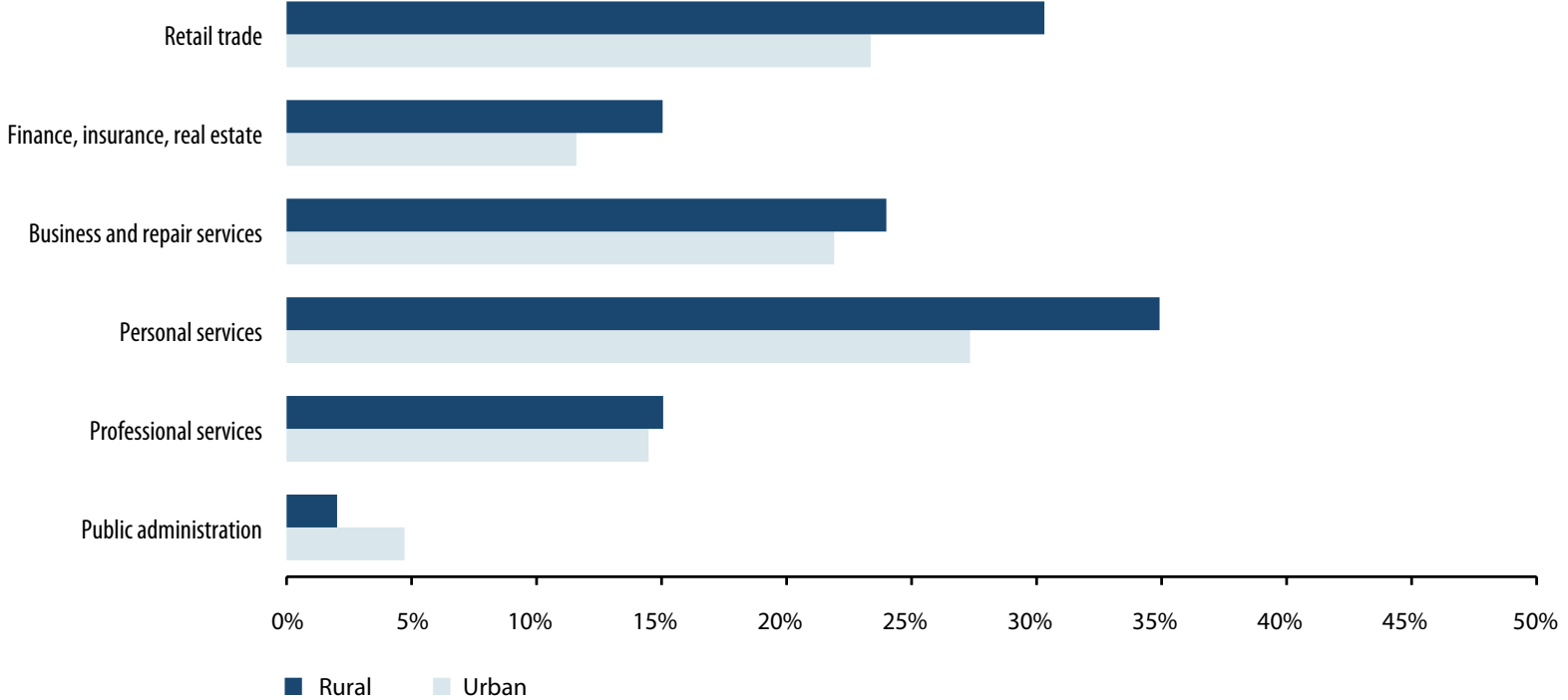

Source: National Longitudinal Survey of Youth 2000-2006. 
work in manufacturing), industrial differences account for only a small fraction of the gap between rural and urban mothers. As Figure 3 shows, urban mothers who work in manufacturing, transportation, communication, personal service, and retail trade industries have greater access to paid sick or vacation days than rural mothers who work in these same industries.

Figure 4 presents rural-urban differences in access to paid sick days by establishment size, and Figure 5 presents rural-urban differences in access to any paid sick or vacation days by establishment size. The rural-urban gap in access persists even among those who work in very small establishments, with fewer than twenty-five employees. Almost 50 percent of rural individuals who work in very small establishments do not have access to any paid sick days, whereas only 43 percent of urban individuals who work in very small establishments do not have access to any paid sick days. The differences between rural and urban workers are most pronounced for those who work in very small establishments (fewer than twenty-five employees) or very large establishments (500 or more employees). Among those who work in moderate-size establishments (between 25 and 499 employees), the rural-urban gap nearly disappears.

\section{How Can We Increase Rural Mothers' Access to Family- Friendly Policies?}

U nlike many other high- and middle-income countries, the United States does not provide universal paid leave. Instead, in the United States some employers provide their workers with paid sick days or paid family leave, but many employers do not. The 1993 federal Family and Medical Leave Act (FMLA) requires employers with fifty or more employees to provide twelve weeks of unpaid family leave. Although workers retain their health insurance and their job seniority during their FMLA leaves, the FMLA is a relatively limited social policy. It covers just over half of the workforce. It provides leave only for "serious health conditions" and not for preventative care. It provides only unpaid leave. Workers who need family leave the most are often the least likely to take it, as they cannot forgo pay. Two-thirds of workers who need leaves but do not take them cite income loss as their primary explanation for not taking a leave. ${ }^{8}$

One strategy to increase rural mothers' access to familyfriendly policies is to universally expand all workers' access. In March 2009, Representative Pete Stark (D-CA) along with Representative George Miller (D-NY) and Representative Carolyn Maloney (D-NY) introduced the Family Leave Insurance Act (H.R. 1723). The bill would provide up to twelve weeks of paid leave to workers who need to take time off to care for dependents or to care for themselves. Benefits would be provided through a federal insurance fund equally financed by employers and employees. In most cases, each would contribute 0.2 percent of their pay, which would amount to roughly less than $\$ 7$ per month for the average worker. The benefits would be tiered, and those earning less than $\$ 20,000$ per year would receive 100 percent wage replacement. Middle-income workers (those earning between $\$ 30,000$ and $\$ 60,000$ ) would receive 55 percent wage replacement, and those earning over $\$ 60,000$ would receive 40 to 45 percent, with benefits capped at $\$ 800$ per week. To receive benefits, employees would have to contribute to the insurance fund for at least six months. The bill was referred to the Subcommittee on Workforce Protections in May of 2009.

Certain states and local municipalities have also enacted more generous family leave policies. In 2002, California enacted the Paid Family Leave Insurance Program, which provides six weeks of partial wage replacement to care for a newborn child, newly adopted or fostered child, or a seriously ill child, spouse, or domestic partner. Nearly all private-sector workers in California are eligible. ${ }^{9}$

Fifteen U.S. states are currently considering legislation on paid sick days. New Hampshire is considering legislation that would provide full- and part-time workers with up to 40 hours per year of paid sick leave. To qualify, individuals would have to work for a New Hampshire employer for more than six months.

There is no one federal, universal set of family-friendly policies in the United States. Instead, certain localities require their employers to provide paid family or sick leave, whereas other localities do not. ${ }^{10}$ Certain groups of workers have access to important family and work policies, whereas other groups of workers do not. Although locallevel policies are promising, federal policies may go furthest in reducing disparities among working families. Access to family-friendly policies is neither the only solution to workfamily conflict nor without costs. ${ }^{11}$ Nevertheless, access holds the promise of significantly improving the health and well-being of workers and their families. 


\section{CARSEY INSTITUTE}

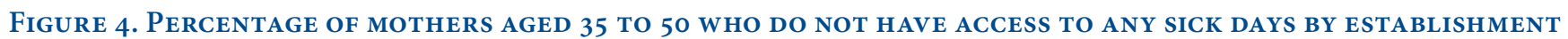
SIZE AND RURAL/URBAN RESIDENCE

500 or more employees

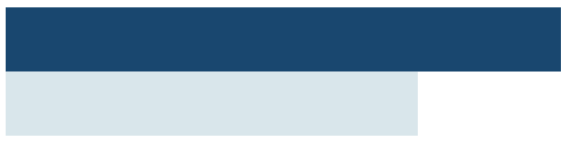

100 to 499 employees

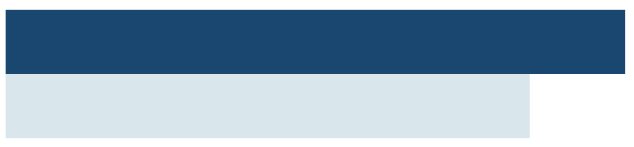

25 to 99 employees

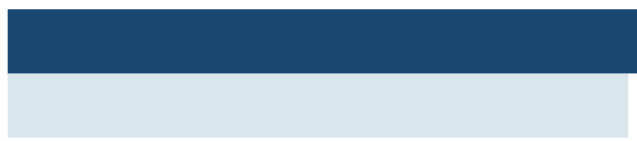

0 to 24 employees

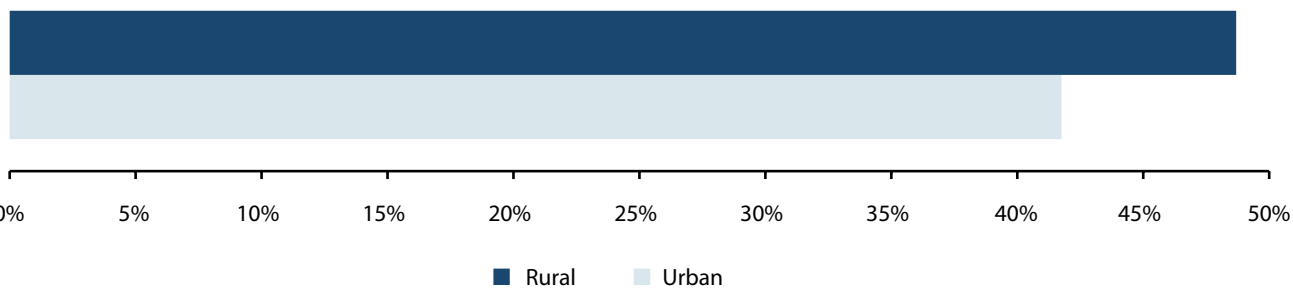

Figure 5. Percentage OF MOTHERS AgED 35 TO 50 WHO do NOT HAVE ACCESS TO ANY SICK OR VACATION DAYS BY ESTABLISHMENT SIZE AND RURAL/URBAN RESIDENCE

500 or more employees

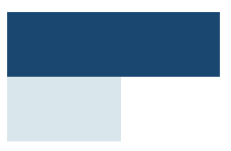

100 to 499 employees

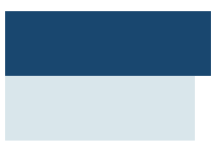

25 to 99 employees

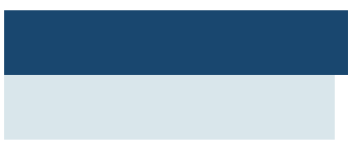

0 to 24 employees
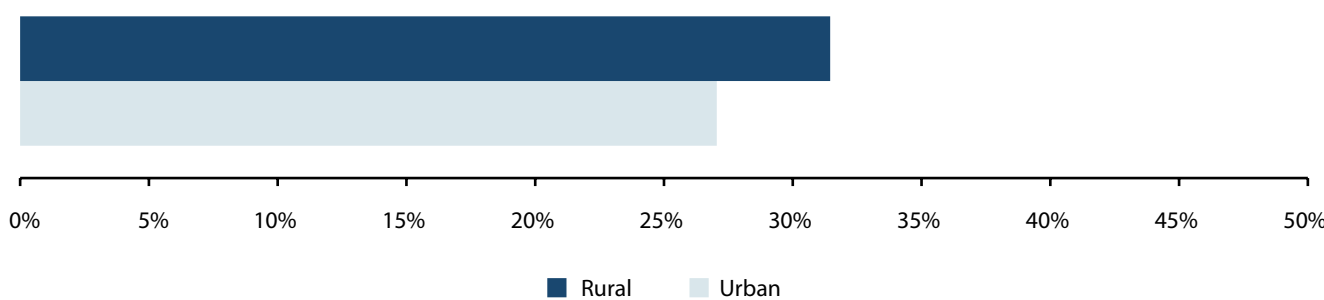


\section{Data}

7 he data used in this report are drawn from the 2000 , 2002, 2004, and 2006 waves of the National Longitudinal Survey of Youth (NLSY). The NLSY is a national probability sample of 12,686 individuals. The survey was first fielded in 1979 by the U.S. Bureau of Labor Statistics to women and men who were between the ages of 14 and 22 . These individuals were interviewed every year until 1994 and then every other year from 1994 to 2006. All analyses presented in this report use sample weights to produce nationally representative estimates.

The NLSY uses the 1990 U.S. Census Bureau urban and rural definitions. In short, the Census Bureau defines nonrural places as "closely settled, named, communities that generally contain a mixture of residential, commercial, and retail areas, and have a population greater than 2,500." For simplicity, these non-rural places are termed "urban" in this report. See "U.S. Census Bureau Urban and Rural Definitions" at http://www.census.gov/population/censusdata/ urdef.txt.

Given the 1990 Census Bureau definitions, 73 percent of NLSY respondents lived in urban areas in 2000 and 27 percent lived in rural areas in 2000. The U.S. Census Bureau revised their definitions in 2000, but the NLSY continued to use the 1990 definitions. Using the revised 2000 definitions, the Census Bureau estimates that 79 percent of Americans lived in urban areas in 2000 and 21 percent lived in rural areas. Thus, there is a small percentage of NLSY individuals who may live in areas that are classified as rural in this report but would not be classified as rural using the updated 2000 Census Bureau definition.

\section{E N D N O T E S}

1. Wei-Jun Han, Christopher J. Ruhm, Jane Waldfogel, and Elizabeth Washbrook, "The Timing of Mothers' Employment after Childbirth," Monthly Labor Review 131(2008): 15-27.

2. Ellen Galinsky, Ask the Children: The Breakthrough Study That Reveals How to Succeed at Work and Parenting (New York: Harper, 2000).

3. Over a third of wage and salary workers have provided elder care in the past year. See James T. Bond, with Cindy Thompson, Ellen Galinsky, and David Prottas, "Highlights of the National Study of the Changing Workforce" (New York: Families and Work Institute, 2002), http://familiesandwork.org/site/research/summary/nscw2002summ.pdf.

4. The term "fringe benefits" usually includes health insurance, dental insurance, and training, whereas the terms "family-friendly policies" or "family-friendly benefits" are often used to describe on-site child care and flexible work programs. Perry-Jenkins argues that flexible work arrangements are usually not available to low-income workers and that researchers should broaden their conceptions of "family-friendly" to include a range of policies. See Maureen Perry-Jenkins, "Work in the Working Class: Challenges Facing Families," in Work, Family, Health, and WellBeing, ed. Suzanne M. Bianchi, Lynne M. Casper, and Rosalind Berkowitz King (Mahwah, NJ: Lawrence Erlbaum, 2005), 449-468.

5. Turnover costs for salaried workers can equal up to 150 percent of their annual pay, and turnover costs for hourly workers can equal up to 75 percent of their annual pay. See Heather Boushey, Layla Moughari, Sarah Sattelmeyer, and Margy Waller, "Work-Life Policies for the Twenty-First Century Economy" (Washington, DC: The Mobility Agenda, 2008). A recent analysis by Vicky Lovell found that in the city of Milwaukee, the cost to employers of implementing a paid sick leave policy was about $\$ 23$ million, whereas the savings for reduced employee turnover was about \$36 million. See Vicky Lovell, "Valuing Good Health in Milwaukee: The Costs and Benefits of Paid Sick Days," IWPR No. B261 (Washington, DC: Institute for Women's Policy Research).

6. Jody Heymann, Forgotten Families: Ending the Growing Crisis Confronting Children and Working Parents in the Global Economy (New York: Oxford University Press, 2006).

7. Logistic regression models are available from the author on request.

8. Naomi Gerstel and Katherine McGonagle, "Job Leaves and the Limits of the Family and Medical Leave Act: The Effects of Gender, Race, and Family," Work and Occupations 26(1999): 510-534.

9. Sarah Fass, "Paid Leave in the States: A Critical Support for LowWage Workers and their Families" (New York: National Center for Children in Poverty, Mailman School of Public Health, Columbia University, March 2009).

10. See Boushey et al., "Work-Life Policies for the Twenty-First Century Economy."

11. Many workers fear that they will be penalized for taking family or medical leaves or for working flexible schedules. See Joan Williams, Unbending Gender: Why Family and Work Conflict and What to Do About It (New York: Oxford University Press, 2001); Kim A. Weeden, "Is There a Flexiglass Ceiling? Flexible Work Arrangements and Wages in the United States," Social Science Research 34(2005): 454-482. 


\section{A BOUT THE AUTHOR}

ReBECCA Glauber is an assistant professor of sociology at the University of New Hampshire and a faculty fellow at the Carsey Institute. (rebecca.glauber@unh.edu)

\section{ACKNOW LE D G M EN TS}

The author would like to thank Mil Duncan, Ken Johnson, Kristin Smith, and Sally Ward, all of the Carsey Institute at the University of New Hampshire, for helpful comments and suggestions.

\section{口.

This piece is printed on Mohawk $100 \%$ recycled paper, which is manufactured entirely with Green-e certified wind-generated electricity. 